\title{
Reaproveitamento do resíduo de gesso na execução de revestimento interno de vedação vertical
}

\author{
Reuse of gypsum waste in the execution of internal \\ coating of partition walls
}

Yêda Vieira Póvoas Tavares Escola Politécnica de Pernambuco Universidade de Pernambuco Te.: (81) 3184-7566 E-mail: yeda.povoas@gmail.com

Alberto Casado Lordsleem Júnior

Escola Politécnica de Pernambuco Universidade de Pernambuco Tel.: (81) 3184-7566 E-mail: acasado@upe.poli.br

Italo Benjamin Telles Arruda Schmitz Escola Politécnica de Pernambuco Universidade de Pernambuco Rua Benfica, 455, Madalena Recife - PE - Brasil CEP 50720-001 Tel.: (81) 2119-3847 E-mail: italobschmitz@yahoo.com.br

Vanderley Moacyr John Departamento de Engenharia de Construção Civil, Escola Politécnica Universidade de São Paulo Av. Almeida Prado, Trav. 2, n. 87, Cidade Universitária São Paulo - SP - Brasil CEP 05508-900 Tel.: (11) 3091-5794 E-mail:vmjohn@poli.usp.br

Recebido em 15/07/09 Aceito em 12/11/09

\section{Yêda Vieira Póvoas Tavares \\ Alberto Casado Lordsleem Júnior Italo Benjamin Telles Arruda Schmitz Vanderley Moacyr John}

\section{Resumo}

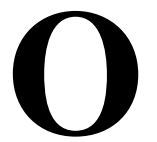

gesso está sendo utilizado em larga escala como revestimento interno de paredes por ser um material barato e de alto desempenho. No entanto, há uma grande geração de resíduo, o que constitui um problema econômico e ambiental. Embora se observe um interesse crescente no uso desse resíduo como revestimento de vedação interna, há um grande desconhecimento a respeito de sua tecnologia de produção, bem como de seu comportamento. O objetivo desta pesquisa é estudar o desempenho desse material através dos ensaios de dureza superficial, resistência à compressão e de aderência, além da apresentação da técnica de execução do revestimento a partir do aproveitamento do resíduo de gesso. Foram realizados ensaios utilizando-se misturas com 0\%, 5\% e 10\% de resíduo com 0,6 mm de diâmetro máximo, e também realizadas visitas técnicas aos canteiros de obras para a avaliação e a determinação da técnica de execução mais apropriada para a aplicação do revestimento. Os resultados mostraram que a adição de resíduos não prejudica excessivamente as propriedades estudadas, sendo admissível até $10 \%$ de resíduo de gesso na produção da nova argamassa, respeitando-se as recomendações da técnica construtiva.

Palavras-chave: Reciclagem. Gesso. Resíduo. Revestimento.

\section{Abstract}

Gypsum is being used on a large scale as internal wall coating because it is a lowcost and high-performance material. However, a large amount of waste is generated in this process, which is an economic and environmental problem. Although there seems to be growing interest in the use of this type of waste as coatings for internal walls, very little is known about its production technology and behavior. The aim of this research study is to investigate the performance of this material by using surface hardness, compressive strength and adhesion tests, as well as to describe the use of gypsum waste in this coating technique. Those tests were carried out using mixes with $0 \%, 5 \%$ and $10 \%$ waste with $0.6 \mathrm{~mm}$ maximum diameter. Also, technical visits to building sites were undertaken in order to assess and determine the most appropriate coating technique. The results indicated that the addition of waste does not worsen the properties investigated, and up to $10 \%$ of gypsum waste is admissible in the production of new plaster, in conformity with building technique recommendations.

Keywords. Recycling. Gypsum. Waste. Coating. 


\section{Introdução}

Cerca de $95 \%$ da produção nacional de gesso natural é oriunda do estado de Pernambuco, do polo gesseiro do Araripe. Desses $95 \%$, ou seja, da produção de 1,3 milhão de toneladas/ano, $61 \%$ são destinados à fabricação de blocos e placas, $35 \%$ para revestimento, 3\% para moldes cerâmicos e $1 \%$ para outros usos (SINDUSGESSO, 2009). O polo gesseiro oferece cerca de 12 mil empregos diretos e aproximadamente $60 \mathrm{mil}$ indiretos, e possui um faturamento anual de US\$ 300 milhões/ano (SINDUSGESSO, 2009).

Na construção civil a utilização do gesso está cada vez maior, pois sua pasta é vista pelas construtoras como um material alternativo de qualidade e de baixo custo para ser aplicado em revestimentos internos de paredes.

Além do custo reduzido, verificam-se maior produtividade por parte dos aplicadores, devido à rapidez de execução, e um bom acabamento final, podendo ser aplicado o sistema de pintura sem a necessidade de aplicação da massa corrida. Mas, durante a fase de aplicação, existe grande geração de resíduo devido à alta velocidade de endurecimento do gesso de construção. Estima-se que o índice de desperdício seja equivalente a $45 \%$ (NITA et al., 2004) de todo o gesso utilizado. Essa elevada geração de resíduo causa problemas econômicos e ambientais, devido ao desperdício do material e ao custo elevado para sua correta destinação.

Conforme a resolução no 307 do Conama (2002), os resíduos de gesso estão classificados como classe $\mathrm{C}$, ou seja, ainda não foi desenvolvida uma tecnologia economicamente viável para sua reutilização ou reciclagem. Então, esses resíduos não podem estar misturados com outros materiais, para evitar uma possível contaminação. O desperdício é ainda maior quando as empresas não treinam seus funcionários. As Figuras 1 e 2 mostram a quantidade de resíduo gerado por aplicadores sem treinamento. Por outro lado, existem aquelas empresas que possuem uma preocupação ambiental e oferecem um treinamento para os gesseiros, e também estão reciclando esse material, reaproveitando o resíduo gerado do próprio revestimento. As Figuras 3 e 4 mostram a quantidade de resíduo gerada por um funcionário bem treinado

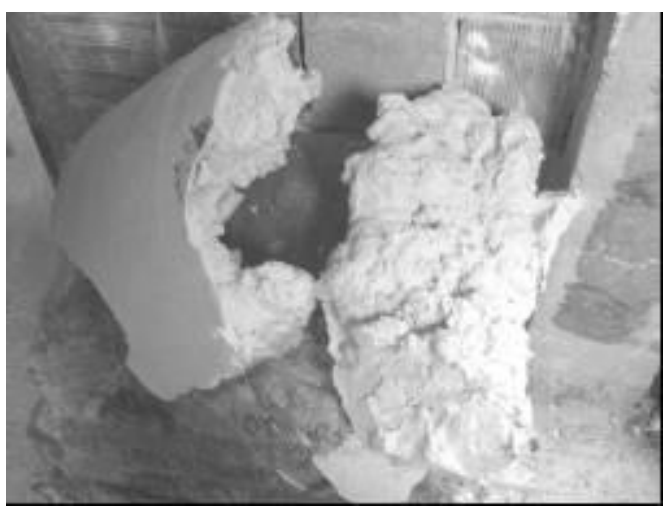

Figura 1 - Resíduo da pasta de gesso proveniente da própria masseira de um aplicador sem treinamento

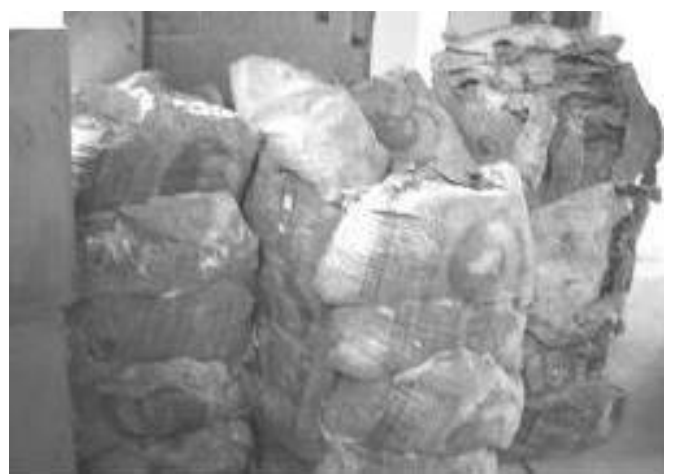

Figura 2 - Resíduo da pasta de gesso gerado em um pavimento revestido por um aplicador sem treinamento 


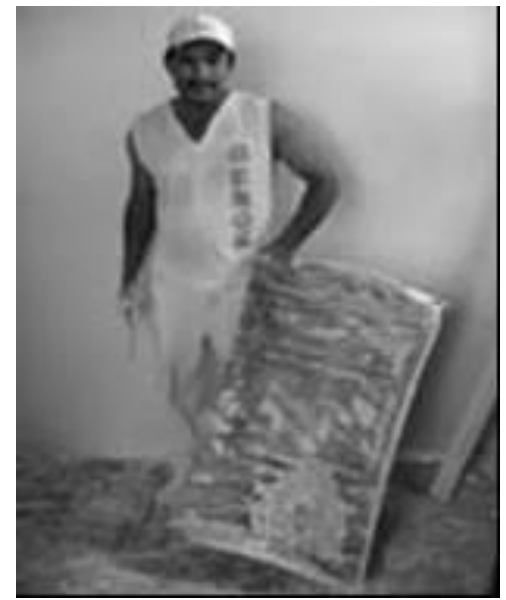

Figura 3 - Resíduo da pasta de gesso gerado na masseira de um aplicador treinado

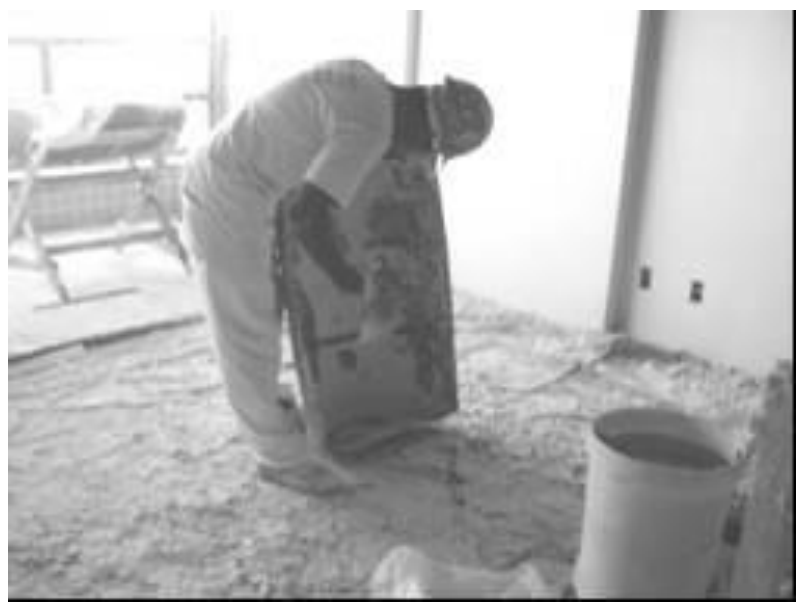

Figura 4 - Resíduo da pasta de gesso gerado em um cômodo revestido por um aplicador treinado

Para o reaproveitamento do resíduo, algumas empresas em Pernambuco estão adicionando até $20 \%$ do resíduo seco ou úmido à mistura sem nenhum tipo de critério.

Embora, por um lado, observe-se um interesse crescente no uso do resíduo de gesso no revestimento interno de vedações verticais de edifícios, notadamente em cidades do Nordeste brasileiro, por outro lado, há um grande desconhecimento a respeito do desempenho, bem como de sua tecnologia de produção, sendo incipientes as pesquisas realizadas no Brasil sobre esse assunto.

Sabe-se que, uma vez que o gesso entra em contato com a água, começa uma reação que transforma o hemidrato no di-hidrato. Essa reação pode ser descrita pela equação 1 (CINCOTTO; AGOPYAN; FLORINDO, 1988).

$\mathrm{CaSO}_{4} \cdot 0,5 \mathrm{H}_{2} \mathrm{O}+1,5 \mathrm{H}_{2} \mathrm{O} \rightarrow \mathrm{CaSO}_{4} \cdot 2 \mathrm{H}_{2} \mathrm{O}+$ calor

Um dos fatores que mais influenciam a reação de hidratação e, consequentemente, o tempo de pega é a relação água/gesso. Quanto maior for essa relação, menor será a cinética da reação de hidratação e maior o tempo de pega, devido à grande quantidade de água que aumenta o intervalo de tempo necessário para saturar a solução.

Os cristais de di-hidrato crescem a partir de núcleos de cristalização ou núcleos. A quantidade de núcleos presentes na solução influencia a taxa de crescimento da microestrutura e o tamanho dos cristais. Quando existem muitos núcleos, o crescimento é rápido e os cristais formados são menores e mais numerosos por unidade de volume (ANTUNES, 1999). Quando há formação de poucos núcleos, o crescimento é lento e são formados cristais maiores em menor quantidade (ANTUNES, 1999). Esses fatores influenciam as propriedades mecânicas da pasta de gesso endurecida, pois microestruturas formadas por cristais grandes são menos resistentes (mais porosas) que as formadas por cristais pequenos (mais densas) (ANTUNES, 1999).

A quantidade de impurezas e de gipsita contidas no gesso acelera a reação de hidratação e o tempo de 
pega por atuarem como núcleos de cristalização (NITA; PILEGGI; CINCOTTO; JOHN, 2004).

Os aditivos controladores de pega interferem na velocidade da reação de hidratação, acelerando-a ou retardando-a. Os aceleradores aumentam a solubilidade do hemidrato. Os retardadores dividem-se em dois grupos, os que ampliam o período de indução (bórax, por exemplo) e os que interferem na cinética da formação da microestrutura do di-hidrato (caseína, por exemplo) (HINCAPIÉ, 1997).

O mecanismo de hidratação pode ser explicado por meio da calorimetria. A curva de calor de hidratação de uma pasta de gesso é apresentada em três etapas (Figura 5) (ANTUNES; JOHN; ANDRADE, 1999), em que, na primeira etapa, ocorre uma pequena hidratação, seguida pelo período de indução. Essa etapa é finalizada quando a taxa de elevação da temperatura ultrapassa 0,1 ${ }^{\circ} \mathrm{C} / \mathrm{min}$, caracterizando o início de pega. A segunda etapa é caracterizada pela rápida elevação da temperatura, ou seja, a hidratação está evoluindo mais rápido. A terceira etapa é o instante em que a reação atinge a temperatura máxima que corresponde à conclusão da hidratação, sendo assim caracterizado o fim de pega.

Essa curva pode ser obtida utilizando-se um calorímetro pseudoadiabático de fácil confecção e, por meio dela, é possível obter o tempo útil do gesso (em torno de $20 \mathrm{~min}$ a $30 \mathrm{~min}$ ), ou seja, a faixa de consistência adequada para sua utilização.

Essa faixa de consistência também pode ser determinada para a argamassa de gesso (pasta + resíduo), ajudando a diminuir o desperdício do material no próprio canteiro de obra, uma vez que a execução do revestimento gera um enorme volume de resíduos, devido a sua velocidade de endurecimento menor que a convencional.

Quanto à técnica de execução do revestimento com resíduo de gesso, ressalta-se a percepção da prática de implantação do reaproveitamento em algumas obras da cidade de Recife, PE, cujas constatações demonstraram a ausência de critério sobre o preparo da nova pasta e a inadequada execução do revestimento. Acrescente-se a falta de conhecimento tecnológico sobre o assunto por parte dos vários agentes envolvidos no processo de produção das vedações: fabricantes dos materiais e componentes, projetistas de revestimento, empresa construtora, subempreiteiros e mão de obra de produção.

O custo de produção pode inclusive ser superior ao planejado e também haver a ocorrência de problemas patológicos, resultando numa rejeição desse produto e inviabilizando-o em obras posteriores, com prejuízo à imagem da construtora.

Nesse contexto, a presente pesquisa tem como objetivo estudar o desempenho do revestimento de gesso com adição de seu resíduo, investigando a resistência de aderência, a resistência à compressão, a dureza superficial e o calor de hidratação, além da apresentação dos principais cuidados a serem observados na técnica de execução do revestimento de vedações verticais.

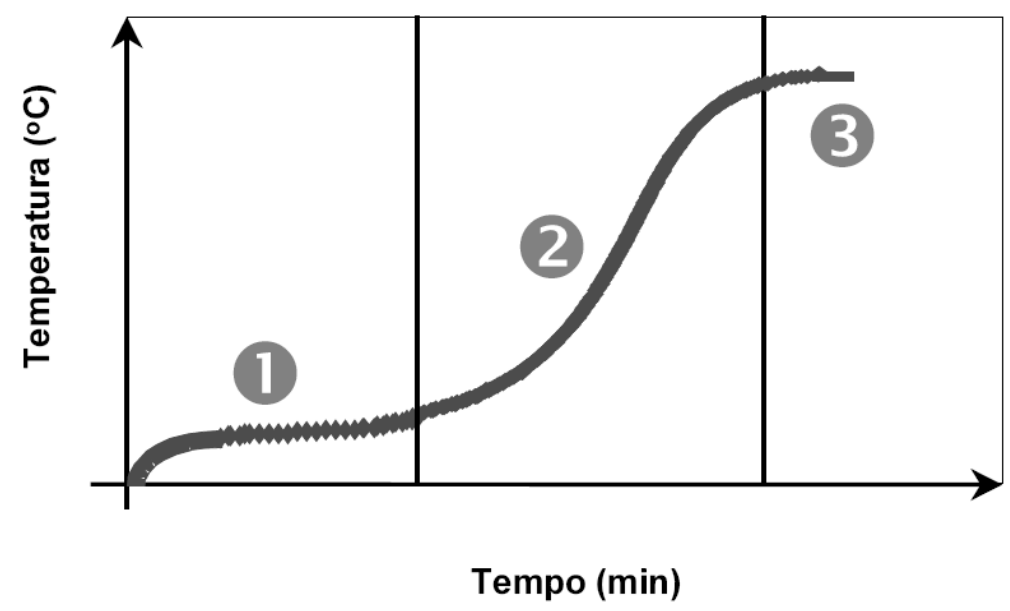

Fonte: Antunes, John e Andrade (1999)

Figura 5 - Exemplo de curva de calor de hidratação de uma pasta de gesso 


\section{Metodologia}

O trabalho está subdividido em duas fases: a primeira, relativa à avaliação de desempenho do revestimento com resíduo de gesso; e a segunda fase, relativa à descrição e aos cuidados pertinentes à técnica de execução do revestimento com o aproveitamento do resíduo de gesso.

\section{Fase 1: ensaios de laboratório}

Em uma primeira etapa do trabalho experimental realizaram-se ensaios mecânicos de resistência à compressão, conforme a norma NBR 12129 (ABNT, 1991), e dureza superficial, calor de hidratação e consistência em laboratório. Para isso foi coletada uma amostra de gesso e quatro amostras do resíduo gerado em quatro obras diferentes. As amostras 1 e 4 foram obtidas em obras que possuíam um sistema de gestão de resíduos implantado e eficiente, enquanto as amostras 2 e 3 foram obtidas em obras que não dispunham de um sistema de gestão de resíduos.

As amostras de resíduo foram beneficiadas manualmente, com um socador, para diminuir sua granulometria. A dimensão máxima foi mantida em 0,6 mm, para deixar o agregado com uma finura próxima à do pó de gesso.

O saco de gesso coletado foi aberto com um corte em formato de cruz (Figura 6) e retirou-se a camada superficial que estava em contato com a embalagem, de modo a coletar o gesso do centro do saco, para garantir uma amostra seca, sendo depositada num recipiente hermeticamente fechado (Figura 7).

Para os ensaios em laboratório foram adotados três tipos de mistura: pastas de gesso com 0\%, 5\% e $10 \%$ de resíduo. Para todas as misturas utilizou-se uma relação água/gesso igual a 0,6, tomando-se como referência a norma NBR 12128 (ABNT, 1991). A mistura da pasta de gesso com adição de resíduo foi denominada argamassa de gesso..

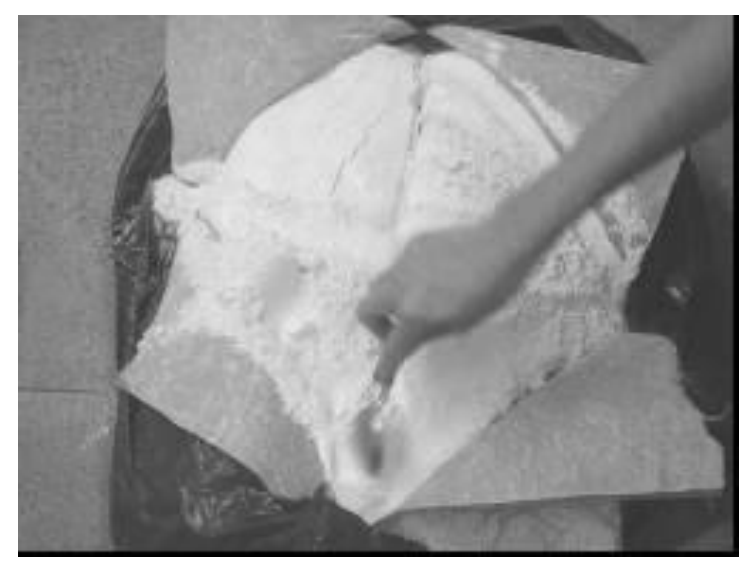

Figura 6 - Retirando a camada superficial do gesso que está em contato com a embalagem

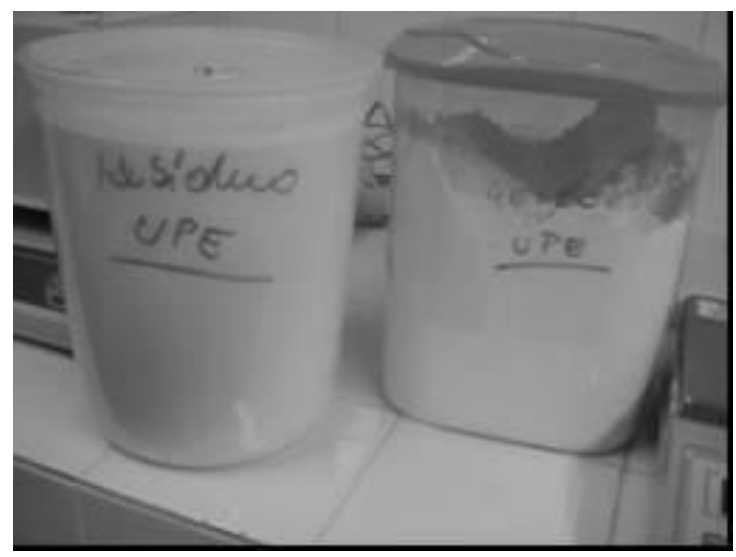

Figura 7 - Armazenamento do gesso do centro do saco em recipiente hermeticamente fechado 
Em uma segunda etapa foram moldados corpos de prova, no canteiro de obras, para a determinação da resistência à compressão e da dureza superficial das argamassas que estavam sendo utilizadas para revestimento, e também foram feitos os ensaios de calor de hidratação e consistência. O resíduo foi adicionado no momento em que a pasta adquiriu uma consistência adequada para ser aplicado. Essa adição foi feita em $1 / 3$ da masseira. Depois que essa parte foi utilizada, o gesseiro adicionou resíduo a mais $1 / 3$ do recipiente, e o outro $1 / 3$ restante continuou sem resíduo, para ser utilizado no acabamento final do revestimento. A mistura foi feita dessa forma porque a adição de resíduo aumenta a velocidade de endurecimento da pasta. A adição de $10 \%$ de resíduo em cada $1 / 3$ do recipiente foi realizada a partir da medição em balança.

Posteriormente, foram feitos os ensaios de resistência de aderência para as proporções $0 \%$, $5 \%$ e $10 \%$ das argamassas produzidas em laboratório

\section{Moldagem dos corpos de prova e ensaio de resistência à compressão}

No laboratório, os corpos de prova foram moldados conforme a NBR 12129 (ABNT, 1994), num molde com três compartimentos, que permite a moldagem simultânea de três corpos de prova cúbicos de $50 \mathrm{~mm}$ de aresta.

Em obra, a pasta foi retirada da parte da masseira onde o gesseiro adicionou o resíduo de gesso e foi colocada no molde. $\mathrm{O}$ resíduo utilizado em obra era beneficiado com uma peneira de abertura próxima de $1 \mathrm{~cm}$. Depois da moldagem e secagem dos corpos de prova, que levou em média 10 dias, foram feitos os ensaios de resistência à compressão e dureza superficial. O ensaio de dureza foi feito com o durômetro Shore C.

Para o ensaio de compressão, a face dos corpos de prova, exceto a superior, foi posicionada no centro da placa da prensa e foi submetida a uma carga contínua com razão de $250 \mathrm{~N} / \mathrm{s}$ até a ruptura. Após registrar a carga equivalente para romper o corpo de prova, a tensão, em MPa, foi calculada pela razão entre a carga (Newtons) e a área da face $\left(\mathrm{mm}^{2}\right)$

\section{Ensaio de resistência de aderência}

Todo o ensaio de resistência de aderência foi desenvolvido apenas na obra da amostra, devido à falta de gesseiros disponíveis na obra 4 para executar os panos necessários para o ensaio. Entende-se como pano quando os pontos ensaiados referentes a um mesmo sistema de revestimento estiverem compreendidos numa área menor ou igual $1,00 \mathrm{~m}^{2}$.

O resíduo utilizado nesse ensaio foi caracterizado por meio da termogravimetria (TG), para verificação dos constituintes e do resíduo insolúvel existente, e da difração de raios X (DRX).

Nas curvas da DTG da Figura 8, é possível observar dois picos distintos, o primeiro em torno de $150{ }^{\circ} \mathrm{C}$, referente à perda de 1,5 molécula de água, e o segundo em $190{ }^{\circ} \mathrm{C}(1 / 2$ molécula de água). A primeira perda de massa foi equivalente a $14,79 \%$ da massa total, perdendo mais $4,79 \%$ até o segundo pico, totalizando $19,58 \%$, valor este menor do que o estimado por cálculo estequiométrico (20,99\%) (NITA et al., 2004).

O gráfico da Figura 9 mostra que a amostra de resíduo utilizado era formada, em maior quantidade, por gesso hidratado e, em menores proporções, hemidrato e anidrita.

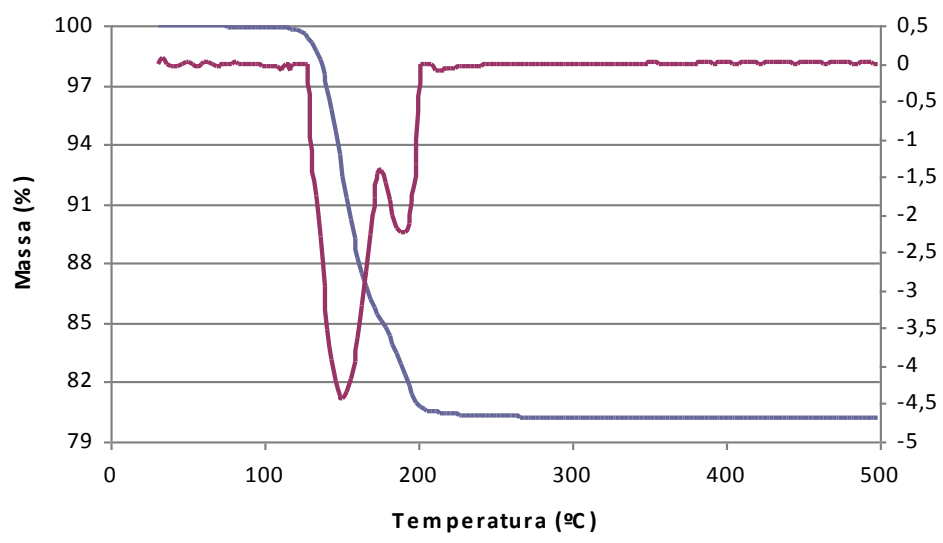

Figura 8 - TG do resíduo de gesso da obra 1 


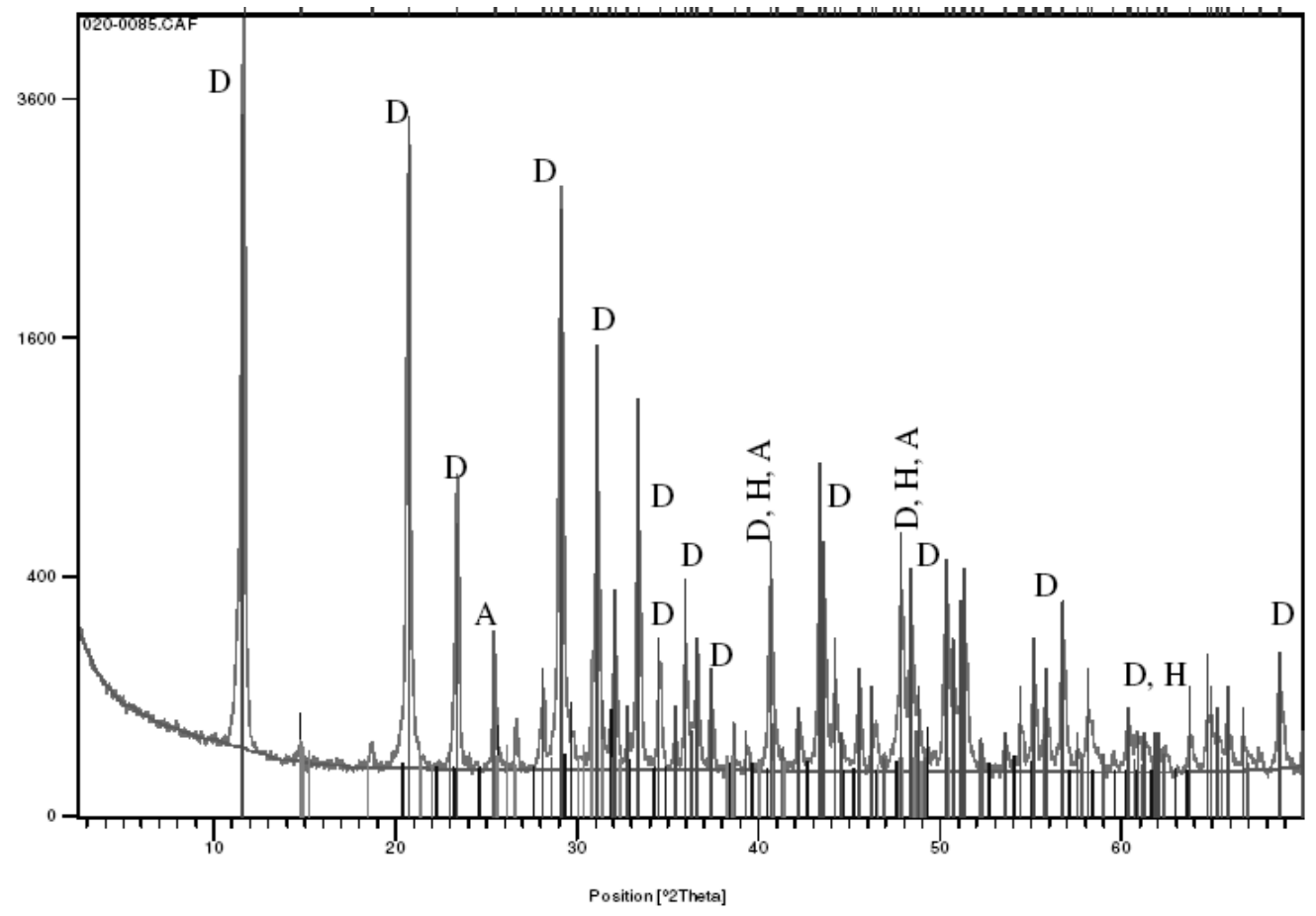

Figura 9 - DRX do resíduo de gesso da obra 1

Para o ensaio de resistência de aderência foram feitos três panos, um para cada quantidade de resíduo adicionado à pasta $(0 \%, 5 \%$ e $10 \%)$. A pasta e as argamassas foram preparadas e aplicadas pelo mesmo gesseiro (Figuras 10 e 11), para diminuir as variáveis do ensaio. A forma de mistura foi a comumente realizada na obra, mediante a introdução de água na masseira, polvilhamento do gesso e, após o início da pega, adição do resíduo. A relação água/gesso próxima de 0,7 foi medida em massa por meio de balança.

Depois que os panos estavam prontos e secos, o revestimento foi cortado com uma serra circular da marca Makita, formando quadrados com lado igual a $5 \mathrm{~cm}$. Pastilhas de aço de mesmo tamanho foram coladas com cola epóxi e, depois de $24 \mathrm{~h}$, foi feito o ensaio de resistência de aderência, com o auxílio de um aderímetro, aplicando uma velocidade de carga de $0,25 \mathrm{kgf}$ até o rompimento.

Em cada pano, a tensão média foi calculada a partir da média das tensões que não diferiam mais que $20 \%$ entre si.

\section{Ensaio de calor de hidratação e consistência}

A calorimetria é capaz de obter curvas de calor de hidratação em função do tempo; através destas, é possível medir os tempos de início e fim de pega. O início de pega é caracterizado quando a taxa de elevação da temperatura ultrapassa $0,1{ }^{\circ} \mathrm{C} / \mathrm{min}$, e o fim de pega é o instante em que a temperatura máxima é atingida. É importante esclarecer que tanto em obra quanto em laboratório foi utilizado um calorímetro pseudoadiabático semelhante ao utilizado por Antunes (1999) e um cronômetro. Cabe também ressaltar que, após a coleta, foram gerados os gráficos das curvas de calor de hidratação e, então, obtidos os tempos de início e fim de pega.

O calorímetro pseudoadiabático foi confeccionado com um recipiente de isopor que isola a amostra do meio externo. Para medir a variação da temperatura foi utilizado um termômetro com resolução de $0,1{ }^{\circ} \mathrm{C}$ com um termopar do tipo $\mathrm{K}$ (Cromel-Alumel) acoplado. A Figura 12 mostra o esquema do calorímetro.

Em laboratório, a amostra foi coletada depois do final do polvilhamento. E na obra, a amostra foi retirada da parte da masseira onde o gesseiro adicionava o resíduo, pois nesse momento a relação água/gesso está fixada. Logo após, a amostra foi colocada dentro de um recipiente plástico, onde foi inserido o termopar fixado a uma rolha, para garantir seu posicionamento no meio da amostra. A amostra com o termopar foi colocada dentro do isopor lacrado para isolar o conjunto do meio externo, e a cada $1,5 \mathrm{~min}$ a temperatura foi registrada. $\mathrm{O}$ tempo zero foi considerado como o instante em que o gesso entra em contato com a água. 


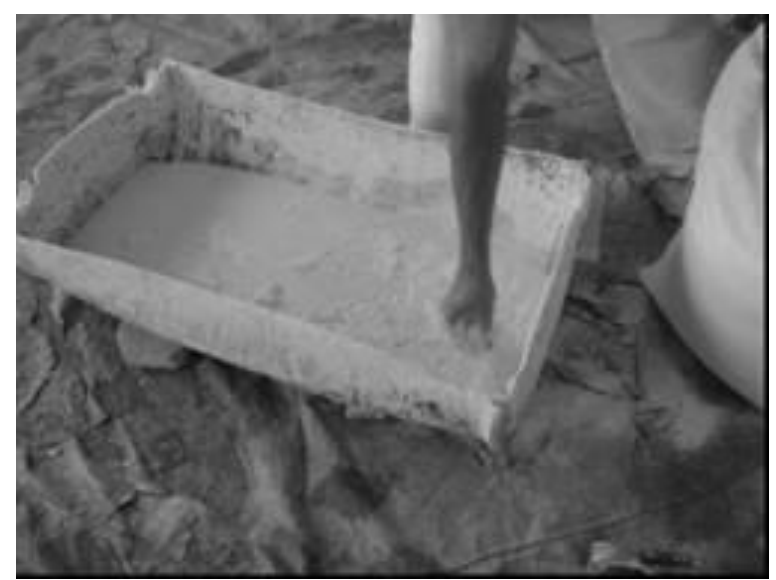

Figura 10 - Preparação da pasta

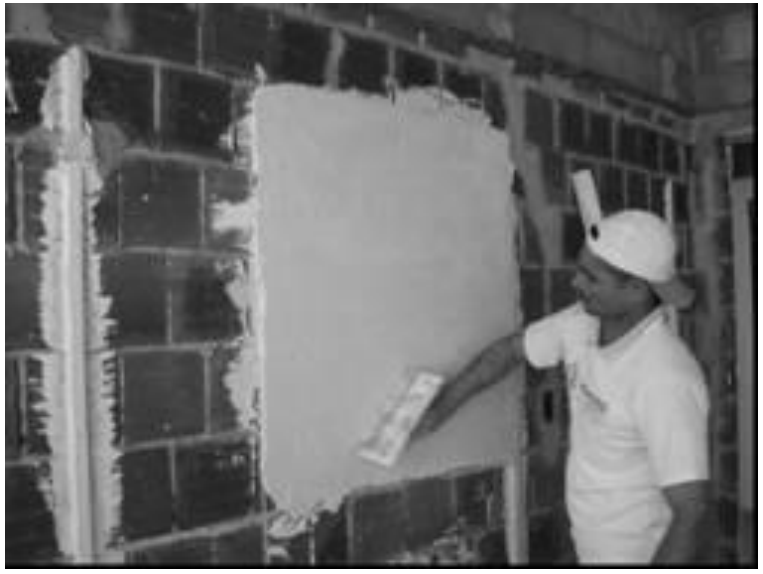

Figura 11 - Aplicação dos panos

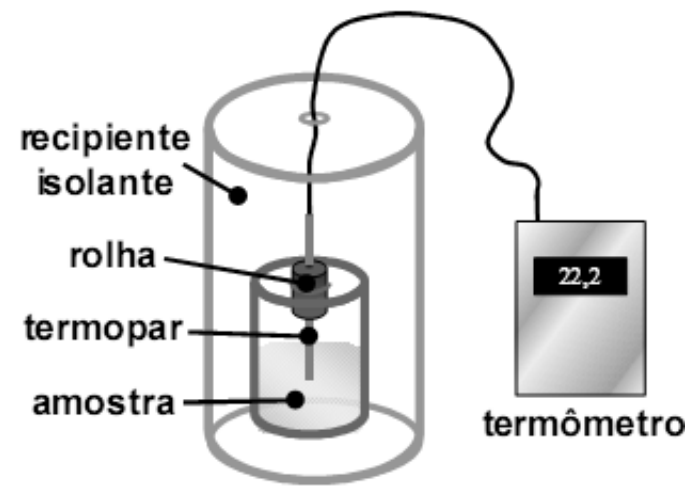

Fonte: Antunes (1999)

Figura 12 - Esquema do calorímetro pseudoadiabático

O ensaio de consistência foi feito com o aparelho de Vicat modificado (Figura 13), utilizando a pasta ou a argamassa da masseira, cujo material estava sendo retirado pelo gesseiro para fazer a aplicação do revestimento. A leitura foi feita conforme a norma NBR 12128 (ABNT, 1991).

Para a consistência, a primeira leitura, correspondente à consistência mínima para aplicação, foi feita no instante em que o gesseiro começou a aplicação do revestimento, e a última leitura, que equivale à consistência máxima, foi feita quando a pasta, ou a argamassa, não estava mais em condições de ser utilizada, caracterizando, assim, uma faixa de consistência útil. 


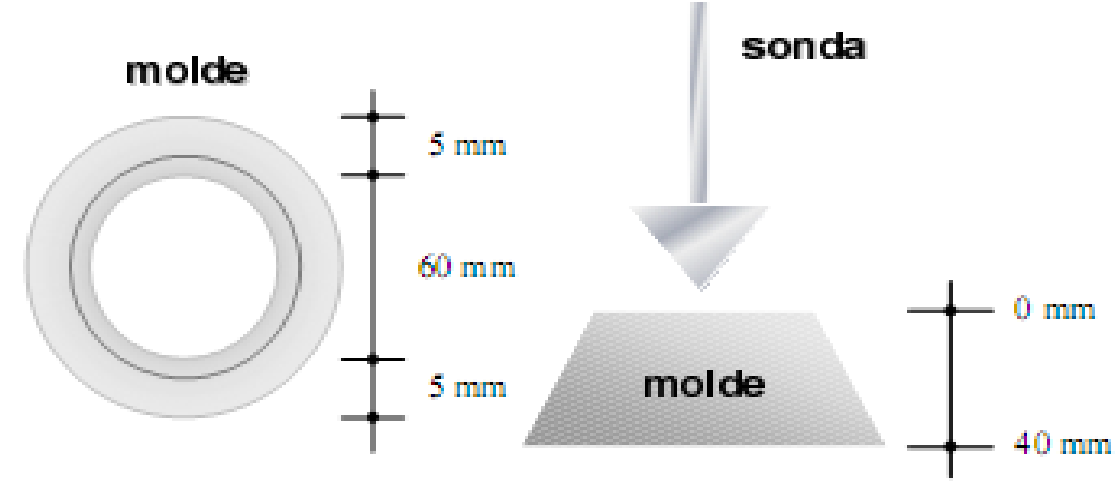

Fonte: Antunes (1999)

Figura 13 - Aparelho de Vicat modificado

\begin{tabular}{c|c|c|c|c|c|c}
\hline Determinações & $\begin{array}{c}\text { Limites da } \\
\text { NBR 13207 (\%) }\end{array}$ & \multicolumn{5}{c}{ Resultados (\%) } \\
\hline & & Gesso & Obra 1 & Obra 2 & Obra 3 & Obra 4 \\
\hline Água livre & máx. 1,3 & 0,64 & 14,91 & 9,22 & 0,15 & 0,44 \\
\hline $\begin{array}{c}\text { Anidrido sulfúrico } \\
\left(\mathbf{S O}_{3}\right)\end{array}$ & mín. 53,0 & 53,79 & 44,91 & 44,38 & 46,18 & 38,00 \\
\hline $\begin{array}{c}\text { Óxido de cálcio } \\
(\mathbf{C a O})\end{array}$ & mín. 38,0 & 38,16 & 32,12 & 32,05 & 32,87 & 27,91 \\
\hline Resíduos insolúveis & - & 0,92 & 2,10 & 4,6 & 17,70 & 0,93 \\
\hline
\end{tabular}

Tabela 1 - Propriedades químicas

\section{Fase 2: visitas técnicas}

Esta fase do trabalho contemplou a realização de visitas técnicas em quatro canteiros de obras, a partir das quais foi possível indicar uma alternativa tecnicamente adequada de reciclagem do resíduo de gesso em pastas para a execução de revestimento interno de parede.

As visitas técnicas foram realizadas nas obras indicadas pelas empresas subempreiteiras aplicadoras de gesso que estão reaproveitando o resíduo em novos revestimentos.

Por ocasião das visitas técnicas foram identificadas diversas variáveis pertinentes aos serviços em execução, das quais cabem ressaltar:

(a) a necessidade de proteção do piso: evitando, assim, a contaminação do resíduo de gesso coletado no chão, resultante da aplicação no revestimento da parede;

(b) o beneficiamento do resíduo gerado: através da realização do apiloamento e trituramento do resíduo de gesso, permitindo obter a granulometria adequada para uso. Esclarece-se que o resíduo de gesso é aquele resultante das sobras da própria obra e na umidade ambiente;

(c) a quantidade de resíduo de gesso em novo revestimento: deve-se respeitar a quantidade-limite estabelecida pelas especificações deste trabalho (5\% a $10 \%)$, considerando ainda as restrições quanto ao tempo de pega, à dureza e à resistência à compressão;

(d) a restrição quanto ao diâmetro resultante do beneficiamento do resíduo de gesso: utilização de diâmetro máximo do resíduo de gesso compatível com a espessura do novo revestimento;

(e) a relação água/gesso: a proporção relativa desses materiais exerce influência direta sobre o tempo de pega, dureza e resistência à compressão; e

(f) a produção do novo revestimento: são considerados fatores influentes da trabalhabilidade da nova argamassa a forma e o tempo de mistura do resíduo de gesso.

\section{Resultados}

\section{Resultados dos ensaios obtidos no laboratório}

Na Tabela 1 estão descritas as propriedades químicas do gesso e dos resíduos estudados.

É possível observar na Tabela 1 que todas as amostras de resíduo apresentaram menos que 53\% de anidrido sulfúrico, como pede a norma NBR 13207 (ABNT, 1994), e também não obtiveram $38 \%$ de óxido de cálcio. 
Os resultados obtidos do estudo das propriedades mecânicas do gesso em ensaios no laboratório estão descritos na Tabela 2.

De acordo com os resultados da Tabela 2, todos os corpos de prova ensaiados apresentaram uma resistência à compressão maior que $8,4 \mathrm{MPa}$, conforme recomendação da NBR 13207 (ABNT, 1994). Ainda pode ser observado, mesmo com os resultados obedecendo aos critérios da norma, que o resíduo diminuiu a resistência e a dureza das argamassas, fazendo com que elas alcançassem um resultado abaixo da pasta de gesso e com que as argamassas com $10 \%$ de resíduo apresentassem uma resistência menor do que aquelas com $5 \%$.

Através da calorimetria foi possível obter curvas de calor de hidratação da pasta e das argamassas com $5 \%$ e $10 \%$ de resíduos de quatro obras diferentes.

Em todas as amostras foi possível observar que a taxa de elevação da temperatura foi maior nas argamassas do que na pasta de gesso. Como consequência, os tempos de início e fim de pega das argamassas foram menores do que os da pasta (Figuras 14, 15, 16 e 17), principalmente nas argamassas com resíduos das obras 2 e 3, onde o fim de pega daquela com $10 \%$ foi menor do que a com 5\% do mesmo resíduo. Já nas argamassas das obras 1 e 4 essa diferença foi menor.

As curvas de calor de hidratação das argamassas das obras 1 e 4, que fazem reutilização do resíduo no próprio revestimento, mostraram-se mais próximas da curva de calor de hidratação da pasta de gesso, ao contrário das argamassas das obras $2 \mathrm{e}$ 3 , que não reutilizam o resíduo gerado em obra. Cabe ressaltar que as amostras de resíduos utilizadas nos ensaios foram coletadas nas próprias obras 2 e 3. Esse fato é devido ao teor de impureza contido na amostra (ver Tabela 1). Os resíduos das obras 1 e 4 são mais limpos, pois os aplicadores colocam uma lona plástica no piso para coletá-los posteriormente.

\begin{tabular}{c|c|c|c}
\hline Mistura de gesso & Quantidade de resíduo & $\begin{array}{c}\text { Resistência à compressão } \\
\text { (MPa) }\end{array}$ & Dureza (u.s.c) \\
\hline Pasta & $0 \%$ & 12,88 & 85,3 \\
\hline \multirow{2}{*}{$\begin{array}{c}\text { Argamassa da } \\
\text { obra 1 }\end{array}$} & $5 \%$ & 11,71 & 84,7 \\
\cline { 2 - 4 } $\begin{array}{c}\text { Argamassa da } \\
\text { obra 2 }\end{array}$ & $10 \%$ & 10,53 & 81,3 \\
\cline { 2 - 4 } Argamassa da & $5 \%$ & 11,61 & 83,6 \\
\cline { 2 - 4 } obra 3 & $10 \%$ & 9,82 & 82,6 \\
\hline $\begin{array}{c}\text { Argamassa da } \\
\text { obra 4 }\end{array}$ & $5 \%$ & 11,59 & 84,7 \\
\cline { 2 - 4 } & $10 \%$ & 10,42 & 81,4 \\
\hline
\end{tabular}

Tabela 2 - Propriedades mecânicas da pasta e da argamassa de gesso moldadas em laboratório

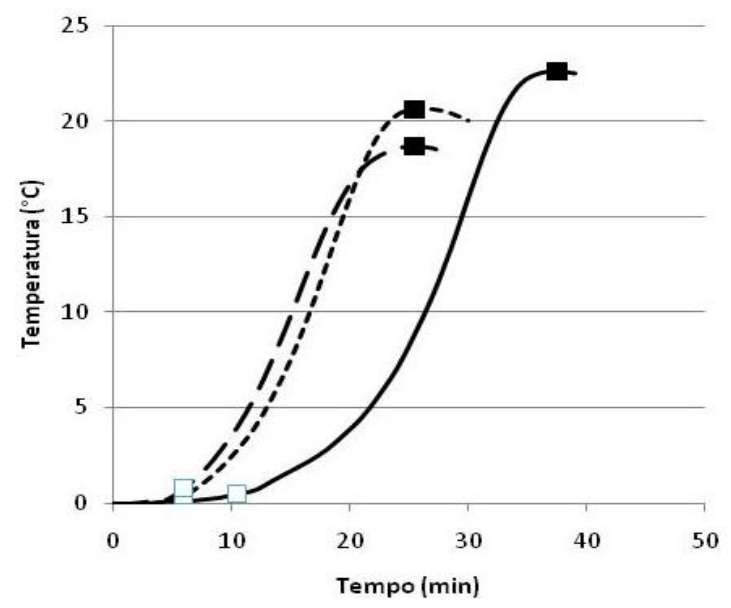

- Curva de calor de hidratação da pasta de gesso natural
-- Curva de calor de hidratação da argamassa de gesso com 5\% de resíduo
-- Curva de calor de hidratação da argamassa de gesso com $10 \%$ de resíduo

Fim da pega

$\square \quad$ Início da pega

Figura 14 - Curvas de calor de hidratação da obra 1

112 Tavares, Y. V. P.; Lordsleem Júnior, A. C.; Schimitz, I. B. T. A.; John, V. M. 


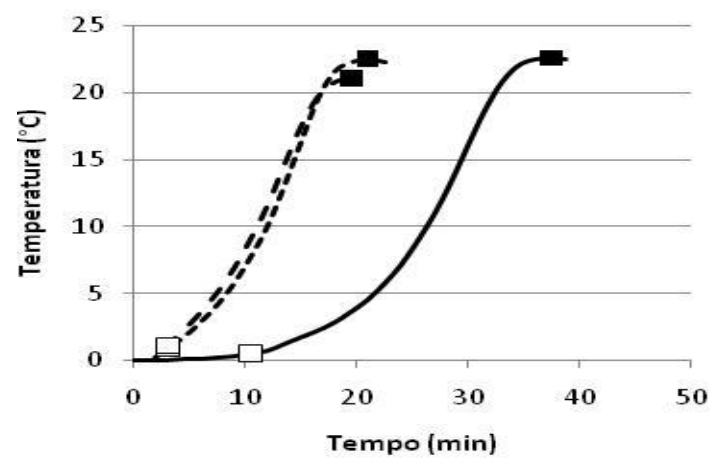

- Curva de calor de hidratação da pasta de gesso natural

-.- Curva de calor de hidratação da argamassa de gesso com $5 \%$ de resíduo

-- Curva de calor de hidratação da argamassa de gesso com $10 \%$ de resíduo

Fim da pega

$\square \quad$ Início da pega

Figura 15 - Curvas de calor de hidratação da obra 4

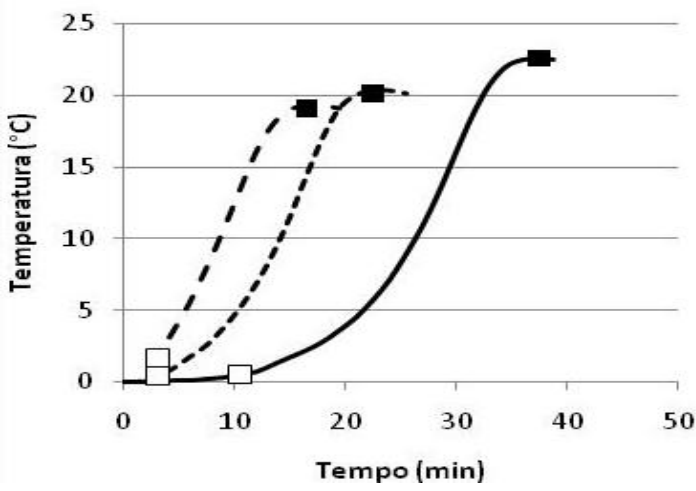

- Curva de calor de hidratação da pasta de gesso natural

-.- Curva de calor de hidratação da argamassa de gesso com $5 \%$ de resíduo

-- Curva de calor de hidratação da argamassa de gesso com $10 \%$ de resíduo

Fim da pega

$\square \quad$ Início da pega

Figura 16 - Curvas de calor de hidratação da obra 2

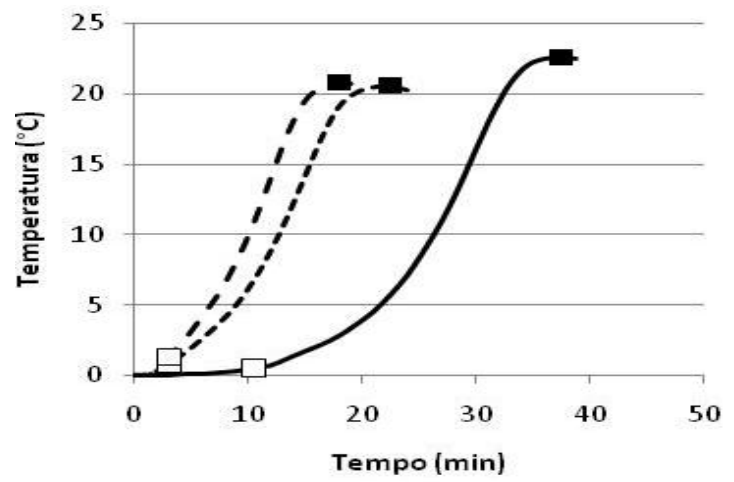

- Curva de calor de hidratação da pasta de gesso natural

-.- Curva de calor de hidratação da argamassa de gesso com $5 \%$ de resíduo

-- Curva de calor de hidratação da argamassa de gesso com $10 \%$ de resíduo

Fim da pega

$\square \quad$ Início da pega

Figura 17 - Curvas de calor de hidratação da obra 3 
Ainda é possível notar que, nas argamassas com resíduos das obras 1 e 4 , as curvas de calor de hidratação referentes às amostras com $10 \%$ de resíduo estavam bem próximas das curvas das argamassas com 5\% dos mesmos resíduos, enquanto, nas argamassas com resíduo das obras 2 e 3, as curvas de calor de hidratação daquelas com $5 \%$ e $10 \%$ de resíduo estavam mais distantes entre si. Isso acontece porque os resíduos das obras 2 e 3 apresentam maior concentração de outros resíduos misturados ao gesso endurecido, que sevem como núcleos de cristalização (NITA et al., 2004).

\section{Resultados dos ensaios obtidos em campo}

Os resultados obtidos em campo foram realizados apenas nas obras 1 e 4, porque essas foram as obras que já estavam reutilizando o resíduo de gesso.

A Tabela 3 mostra os resultados da resistência à compressão da pasta e das argamassas de gesso utilizadas no canteiro de obras.

$\mathrm{Na}$ obra os gesseiros utilizaram uma pasta de relação água/gesso maior que 0,75 (buscou-se não interferir na prática usualmente adotada pela obra, intervalo de tempo comumente adotado entre 20 min e $30 \mathrm{~min}$ ), e por isso o resultado de resistência à compressão da pasta de gesso foi próximo daquela indicada pela norma NBR 13207 (ABNT, 1994). Como a adição de resíduo diminui essa propriedade, as argamassas ficaram um pouco abaixo do que é recomendado.

A Figura 18 ilustra os resultados referentes à resistência de aderência do revestimento feito com a pasta e com as argamassas de gesso da obra 1.

Os resultados deste ensaio mostram que as argamassas obtiveram uma aderência média abaixo daquela obtida pela pasta de gesso. Devido à grande variação dos resultados, as tensões médias foram calculadas desprezando-se os valores distantes $15 \%$ entre si. Com isso todas as misturas apresentaram uma resistência média à tensão maior ou igual a 0,2 $\mathrm{MPa}$, como é recomendado na norma NBR 13528 (ABNT, 1995), para revestimentos internos de parede de argamassas de cimento. Essa norma foi adotada como parâmetro, uma vez que não existe uma norma específica para o revestimento de gesso.

\begin{tabular}{l|c}
\hline Mistura de gesso & Resistência à compressão (MPa) \\
\hline Pasta & 8,12 \\
\hline Argamassa com 10\% de resíduo da obra $\mathbf{1}$ & 6,39 \\
\hline Argamassa com 10\% de resíduo da obra $\mathbf{4}$ & 7,56 \\
\hline
\end{tabular}

Tabela 3 - Resistência à compressão da pasta e das argamassas de gesso moldadas em obra

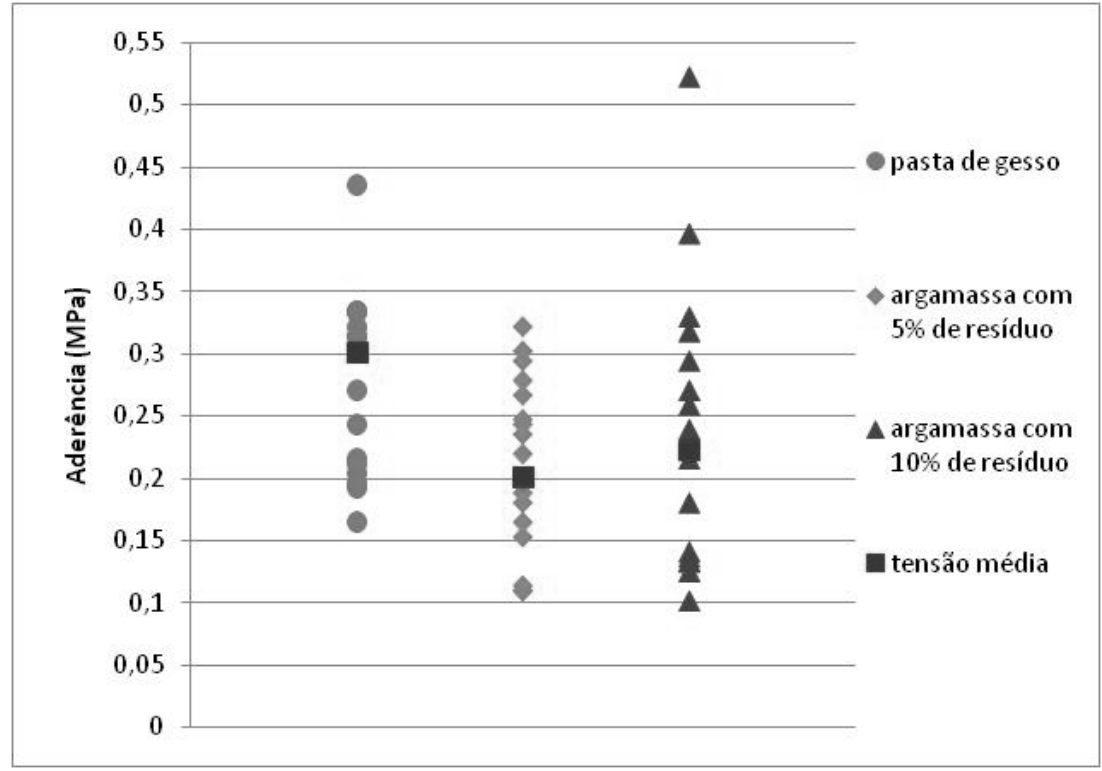

Figura 18 - Resultados de resistência de aderência da pasta e das argamassas de gesso 
Ainda é possível observar que a argamassa com $10 \%$ de resíduo obteve um resultado superior ao da mistura com $5 \%$. Isso pode ter sido causado pela variação da absorção de água de cada tijolo da parede referente aos panos ensaiados, uma vez que o pano referente à argamassa com 5\% de resíduo estava próximo à janela e recebia maior insolação.

Os resultados da Tabela 4 fazem referência ao intervalo de tempo em que a pasta e as argamassas atingem uma consistência mínima para utilização, até o momento em que elas ainda podem ser utilizadas pelo gesseiro. Em paralelo, foi feito o ensaio de calor de hidratação, a fim de determinar em que fase da reação de hidratação estão contidos o início e o fim da utilização.

O momento em que o resíduo é adicionado é muito importante, pois se ele for adicionado depois que a pasta alcançar a consistência mínima, essa adição só vai aumentar a velocidade de endurecimento e acabará gerando mais resíduo. Mas se ele for adicionado um pouco antes disso, o resíduo vai diminuir o tempo de espera da consistência mínima, fazendo com que a argamassa comece a ser utilizada imediatamente.

A proximidade do tempo útil da pasta e da argamassa de gesso da obra 4 deu-se pelo fato de o gesseiro ter utilizado um aditivo retardador de pega, produzido pela própria empresa e não disponibilizado, ampliando assim seu tempo útil.

Para todas as argamassas, os tempos de início e fim de pega foram inferiores aos da pasta.

As curvas de calor de hidratação da pasta e das argamassas estão expressas nas Figuras 19 e 20.

De acordo com as curvas de calor de hidratação, a pasta de gesso adquiriu a consistência mínima antes do início de pega, o que se repetiu na argamassa com resíduo da obra 4.

No caso da argamassa com resíduo da obra 1, o início de sua utilização deu-se um pouco depois do início de pega, porque o resíduo foi adicionado num momento muito próximo deste, fazendo com que a consistência mínima da argamassa ocorresse depois do início de pega.

A pasta e a argamassa de gesso com resíduo da obra 1 atingiram a consistência máxima antes do fim de pega, enquanto a argamassa com resíduo da obra 4 atingiu a consistência máxima praticamente no mesmo momento que o fim de pega, devido à utilização de um aditivo retardador de pega, que interferiu, também, na cinética da formação da microestrutura do di-hidrato, conforme apresentado por Hincapié (1997), em curvas de calor de hidratação, dificultando a análise comparativa.

\begin{tabular}{l|c|c|c}
\hline & Início da utilização (min) & Fim da utilização (min) & Tempo útil (min) \\
\hline Pasta & 17,20 & 44,00 & 26,80 \\
\hline Argamassa - Obra 1 & 19,25 & 32,50 & 13,25 \\
\hline Argamassa - Obra 4 & 12,60 & 35,00 & 22,40 \\
\hline
\end{tabular}

Tabela 4 - Faixa de consistência útil da pasta e das argamassas obtidas nas obras

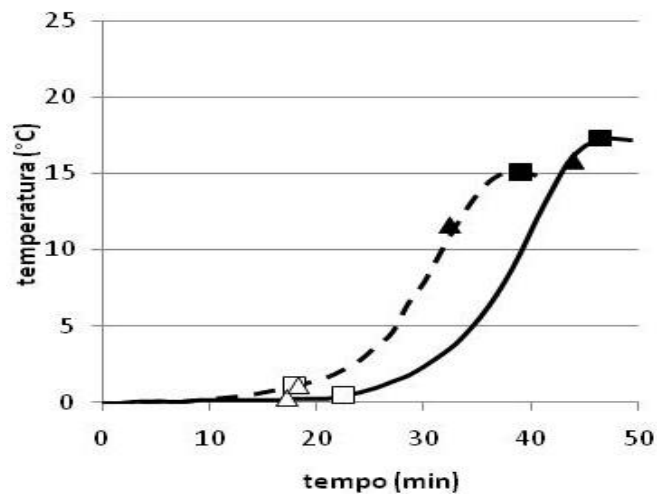

- Curva de calor de hidratação da pasta de gesso obtida no canteiro

- - Curva de calor de hidratação da argamassa de gesso obtida no canteiro

$\square$ Início da pega

Fim da pega

$\Delta$ Consistência máxima

Figura 19 - Curvas de calor de hidratação da pasta e da argamassa de gesso com $10 \%$ resíduo da obra 1 , obtidas no canteiro de obras 


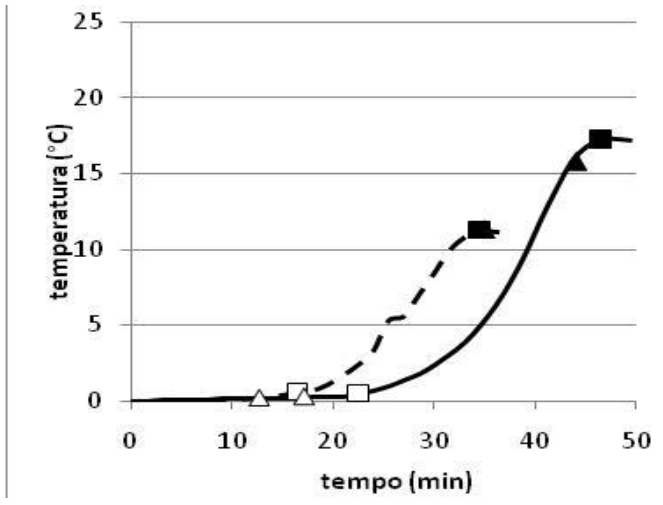

- Curva de calor de hidratação da pasta de gesso obtida no canteiro

- - Curva de calor de hidratação da argamassa de gesso obtida no canteiro

$\square$ Início da pega

Fim da pega

$\Delta$ Consistência máxima

Figura 20 - Curvas de calor de hidratação da pasta e da argamassa de gesso com $10 \%$ resíduo da obra 4, obtidas no canteiro de obras

\section{Técnica de execução}

A seguir estão descritas as etapas de execução do revestimento de gesso com a utilização de seu resíduo, as quais consideram os resultados obtidos na $1^{\mathrm{a}}$ fase desta pesquisa.

As visitas técnicas realizadas permitiram estabelecer as etapas a seguir para a técnica de execução do revestimento de gesso com o aproveitamento do resíduo (Figura 21).

- Etapa 1. Condições de início dos serviços:

(a) a alvenaria deve estar concluída e liberada, assim como as bases de concreto;

(b) proceder a realização da limpeza do substrato com a retirada de pó, desmoldante e graxa. A superfície deve estar isenta de sujeiras em geral, e pontos de ferro (pregos e arames) ou umidade devem ser eliminados;

(c) remover as irregularidades, tais como rebarbas, excessos de argamassa e furos; e

(d) realizar a verificação e o preparo do substrato quanto às condições de prumo, do esquadro e da planeza, de maneira que sejam definidas as espessuras das taliscas e mestras do revestimento, conforme procedimento da empresa.

Devem ser observados cuidados específicos no que diz respeito à fixação prévia e proteção dos caixilhos, assim como das instalações elétricas e dos registros e válvulas hidrossanitárias.
- Etapa 2. Aproveitamento do resíduo de gesso através da proteção do piso:

(a) antes do início da preparação da pasta de gesso, deve-se cobrir o piso com uma lona plástica para impedir que o resíduo gerado na execução do revestimento se misture com outros resíduos, ou prejudique o piso, caso este esteja pronto; e

(b) promover o acondicionamento do resíduo gerado em sacos plásticos, evitando a contaminação com outros resíduos ou materiais deletérios.

- Etapa 3. Definição da superfície através das referências geométricas:

(a) identificar os pontos de maior e menor espessura utilizando esquadro e prumo, e assentar as taliscas nos pontos de menor espessura;

(c) assentar as demais taliscas, iniciando pelas taliscas superiores, com transferência de espessura conforme procedimento da empresa, utilizando fio de prumo ou prumo de face e régua;

(d) as taliscas devem ser assentadas a $30 \mathrm{~cm}$ das bordas das paredes ou teto. O espaçamento das taliscas não deve ser superior a $1,8 \mathrm{~m}$; e

(e) para a execução das mestras ou guias, preparar uma pequena quantidade de pasta de gesso e preencher toda a superfície de uma régua de alumínio. Apoiar a régua nas taliscas, fazendo a pasta entrar em contato com a parede. Quando a pasta endurecer, retirar a régua, e a mestra estará concluída. 


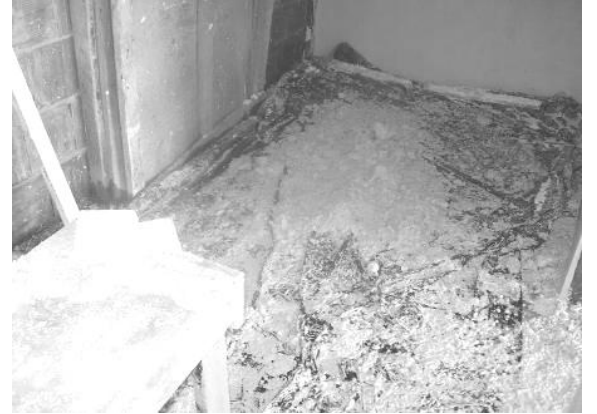

(a) Proteção do piso

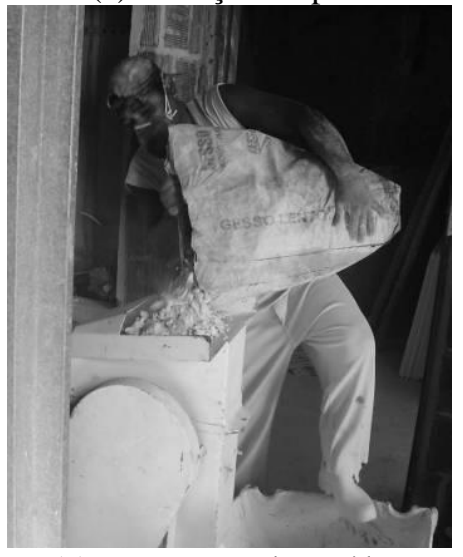

(c) Preparação do resíduo

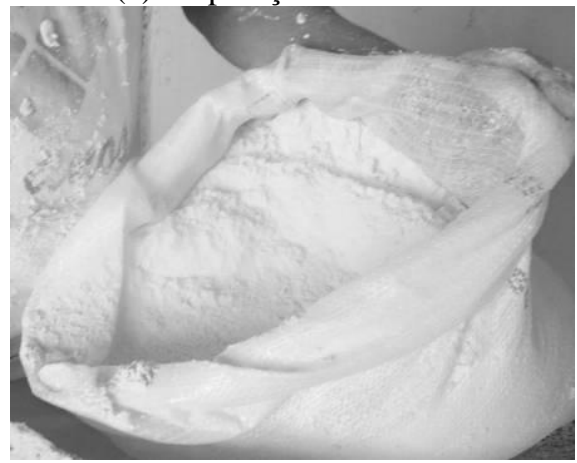

(e) Resíduo acondicionado para a mistura

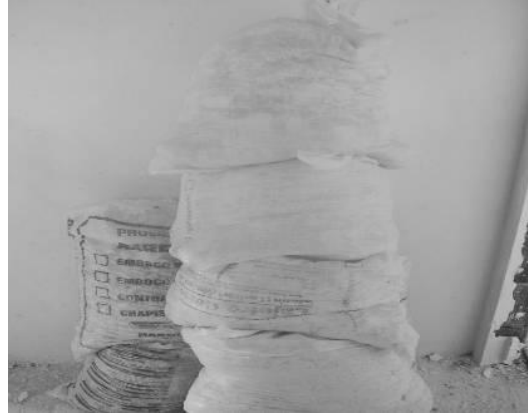

(b) Acondicionamento do resíduo

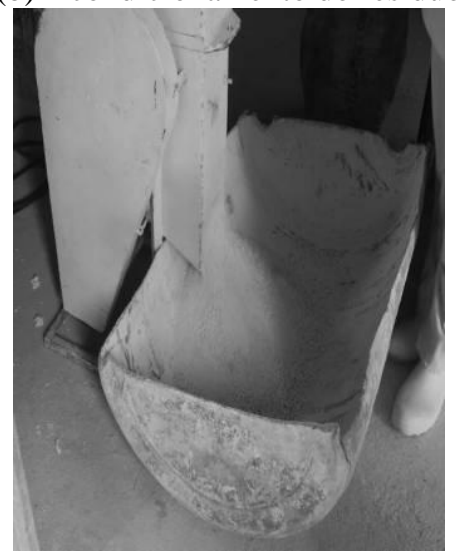

(d) Acondicionamento do resíduo britado

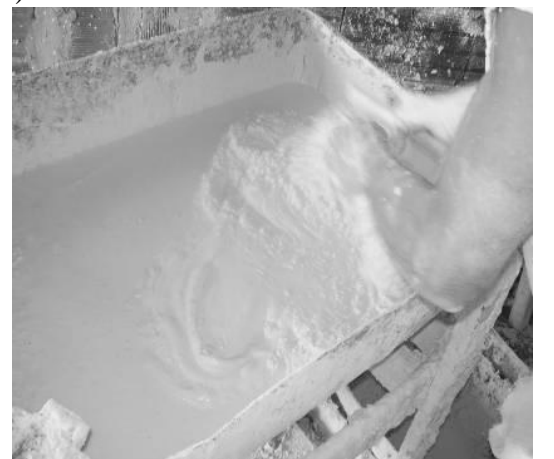

(f) Mistura do resíduo com o gesso natural

Figura 21 - Ilustração de etapas da técnica de execução de revestimento com o aproveitamento de resíduos de gesso

- Etapa 4. Preparação do resíduo de gesso:

(a) deixar o resíduo de gesso secar por, no mínimo, 8 dias, para que possa ser britado, com moinho ou piloador manual, e diminuir o tamanho do resíduo até que ele passe por uma peneira de $1,2 \mathrm{~mm}$ de abertura de malha; e,

(f) a depender da quantidade de gesso a ser utilizado, separar 5\% em massa do resíduo, com relação à massa de gesso a ser aplicada.

- Etapa 5. Preparação da pasta de gesso para execução do revestimento:

(a) colocar água num recipiente e polvilhar o pó de gesso até cobrir toda a superfície da água; (b) quando a pasta adquirir uma consistência boa para começar a aplicação, adicionar metade do resíduo de gesso seco a 1/3 da pasta, misturar e começar a aplicação imediatamente;

(c) depois que o primeiro 1/3 for utilizado, adicionar a outra metade do resíduo de gesso a mais $1 / 3$ da pasta, e o restante continua sem resíduo para facilitar o acabamento; e

(d) a adição do resíduo em cada $1 / 3$ da pasta deve ser realizada a partir da medição em balança.

- Etapa 6. Aplicação da argamassa de gesso:

(a) colocar a argamassa de gesso anteriormente misturada sobre uma desempenadeira de PVC e fazer o espalhamento na parede; ao término da utilização da parte previamente misturada, seguir 
com a utilização da segunda parte, onde foi adicionado o resíduo;

(b) quando a parede estiver coberta com a argamassa, realizar o sarrafeamento com uma régua de alumínio em formato " $\mathrm{L}$ ", apoiando-a nas mestras e fazendo movimentos como se estivesse cortando a massa;

(c) em paredes, sarrafear no sentido vertical e de baixo para cima;

(d) retirar a massa da régua com espátula, chapar novamente nos espaços vazios e passar a régua novamente;

(e) repetir essa operação até que a superfície esteja preenchida e homogênea; e

(f) recomenda-se finalizar os revestimentos de teto para iniciar o revestimento das paredes.

- Etapa 7. Acabamento final:

(a) para realizar o acabamento final, passar uma camada fina da pasta de gesso à qual não foi adicionado o resíduo;

(b) com uma desempenadeira, aplicar a pasta em movimentos horizontais; o excesso deve ser retirado com desempenadeira de aço pequena, em movimentos verticais; e

(c) repetir o processo mais 2 ou 3 vezes, até que a superfície fique lisa.

\section{Conclusões}

A reciclagem do resíduo gerado durante a execução do revestimento de gesso na própria obra mostrou-se viável, pois elimina as disposições incorretas e impede que outros resíduos se misturem a esse material. É importante um efetivo controle de produção para garantir a proporção e a granulometria do resíduo a ser utilizado no revestimento.

As adições de $5 \%$ e $10 \%$ de resíduos de gesso em suas pastas não comprometeram seriamente as propriedades mecânicas de resistência à compressão, dureza superficial e resistência de aderência, visto que os resultados obtidos contemplaram as especificações estabelecidas pelas normas técnicas. Cabe ressaltar que as maiores variações foram de $33 \%$ na resistência de aderência para a argamassa com $5 \%$ de resíduo, e $24 \%$ na resistência à compressão e 5\% na dureza superficial para a argamassa com $10 \%$ de resíduo.

As curvas de calor de hidratação mostraram que a adição de resíduo acelera a hidratação da pasta e, consequentemente, diminui o tempo de pega, o que pode resultar em menor tempo útil de aplicação. No entanto, essa diminuição no tempo de pega pode ser contornada quando o gesseiro adiciona o resíduo a uma parte da masseira, deixando a outra parte com todas as suas propriedades conservadas. Sendo assim, o gesseiro consegue diminuir o tempo necessário para que a pasta alcance a consistência mínima para aplicação, e o fim da utilização continua inalterado, pois nessa parte da masseira não existe a influência da adição do resíduo. Com isso, a faixa de consistência útil das argamassas pode chegar a resultados mais próximos aos da pasta.

Observou-se, como alternativa, a adição de $10 \%$ de resíduo para o reaproveitamento das sobras do revestimento, o que pode diminuir a deposição desse material no meio ambiente.

Finalmente, cabe advertir que a adição do resíduo de gesso deve estar inserida no contexto da adequada técnica de execução do revestimento, atendendo aos cuidados apresentados neste trabalho, de maneira a alcançar o desempenho previsto e a garantir a qualidade do produto acabado.

\section{Referências}

ANTUNES, R. P. N. Estudo da Influência da Cal Hidratada nas Pastas de Gesso. 1999.

Dissertação (Mestrado em Engenharia da Construção Civil) - Escola Politécnica da Universidade de São Paulo, São Paulo, 1999.

ANTUNES, R. P. N.; JOHN, V. M.; ANDRADE, A. C. Produtividade dos Revestimentos em Gesso: influência das propriedades do material. In: SIMPÓSIO BRASILEIRO DE GESTÃO DA QUALIDADE E ORGANIZAÇÃO DO TRABALHO, 1. Recife, 1999. Anais... Recife, 1999.

\section{ASSOCIAÇÃO BRASILEIRA DE NORMAS}

TÉCNICAS. NBR 12128: gesso para construção: determinação das propriedades físicas da pasta. Rio de Janeiro, 1991.

\section{ASSOCIAÇÃO BRASILEIRA DE NORMAS} TÉCNICAS. NBR 12129: gesso para construção: determinação das propriedades mecânicas. Rio de Janeiro, 1991.

\section{ASSOCIAÇÃO BRASILEIRA DE NORMAS}

TÉCNICAS. NBR 13207: gesso para construção.

Rio de Janeiro, 1994. 
ASSOCIAÇÃO BRASILEIRA DE NORMAS TÉCNICAS. NBR 13528: revestimento de paredes e tetos de argamassas inorgânicas: determinação da resistência de aderência à tração. Rio de Janeiro, 1995.

CINCOTTO, M. A.; AGOPYAN, V.; FLORINDO, M. C. O Gesso como Material de Construção, parte II. In: INSTITUTO DE PESQUISAS TECNOLÓGICAS DO ESTADO DE SOÃ PAULO. Tecnologia de Edificações. São Paulo: IPT-PINI, 1988. p 57-60.

CONSELHO NACIONAL DE MEIO

AMBIENTE. Resolução n. 307, de 5 de julho de 2002. Estabelece diretrizes, critérios e procedimentos para a gestão dos resíduos da construção. Diário Oficial da República Federativa do Brasil.

HINCAPIÉ, A. M. Efeito de Substâncias Retardadoras de Pega nas Propriedades do Gesso de Construção. 1997. Dissertação (Mestrado em Engenharia Civil) - Escola Politécnica, Universidade de São Paulo, 1997.
NITA, C. et al. Estudo da Reciclagem do Gesso de Construção. In: CONFERÊNCIA LATINOAMERICANA DE CONSTRUÇÃO SUSTENTÁVEL, 1; ENCONTRO NACIONAL DE TECNOLOGIA DO AMBIENTE CONSTRUÍDO, 10., São Paulo, 2004. Anais... São Paulo: Antac, 2004. 1 CD-ROM.

SINDUSGESSO. Polo Gesseiro. Disponível em: <http://www.sindusgesso.org.br/>. Acesso em: 05 jun. 2009.

\section{Agradecimentos}

O presente trabalho foi realizado com o apoio da CAPES, SEBRAE/PE, POLI/UPE e EPUSP. 